\title{
MALIGNANT MELANOMA OF THE CHOROID IN A CASE OF NAEVUS OF OTA*†
}

BY

\author{
R. FREZZOTTI, R. GUERRA, G. P. DRAGONI, AND P. BONANNI \\ From the Institute of Ophthalmology, University of Siena Medical School, Siena, Italy
}

A PATIENT is presented in whom a malignant melanoma of the choroid developed in association with a naevus of Ota.

The naevus of Ota is quite common in Orientals but occurs far less frequently in Caucasians and Negroes. It is considered an aberrant or misplaced mongolian spot and it rarely undergoes malignant change. Apart from its rarity, malignant change has never been recorded in Orientals and there are only a few reported cases of such a change in Caucasians; in the choroid (Hulke, 1861; Albert and Scheie, 1963; Tosti and Renna, 1966; Makley and King, 1967; Volpi, 1966; Roy and Schaeffer, 1967), in the skin (Dorsey and Montgomery, 1954), in the orbit (possible cases-Benedict, 1949; Reese, 1964; well documented cases-Jay, 1965; Hagler and Brown, 1966), in the iris (Font, Reynolds, and Zimmerman, 1967), and in the brain (Willis, 1960; Gomez Gonzales, Roselli, and Rodriguez, 1965).

\section{Case Report}

A 57-year-old white man complained of impaired vision in the left eye and was referred to the University Eye Clinic in June, 1967.

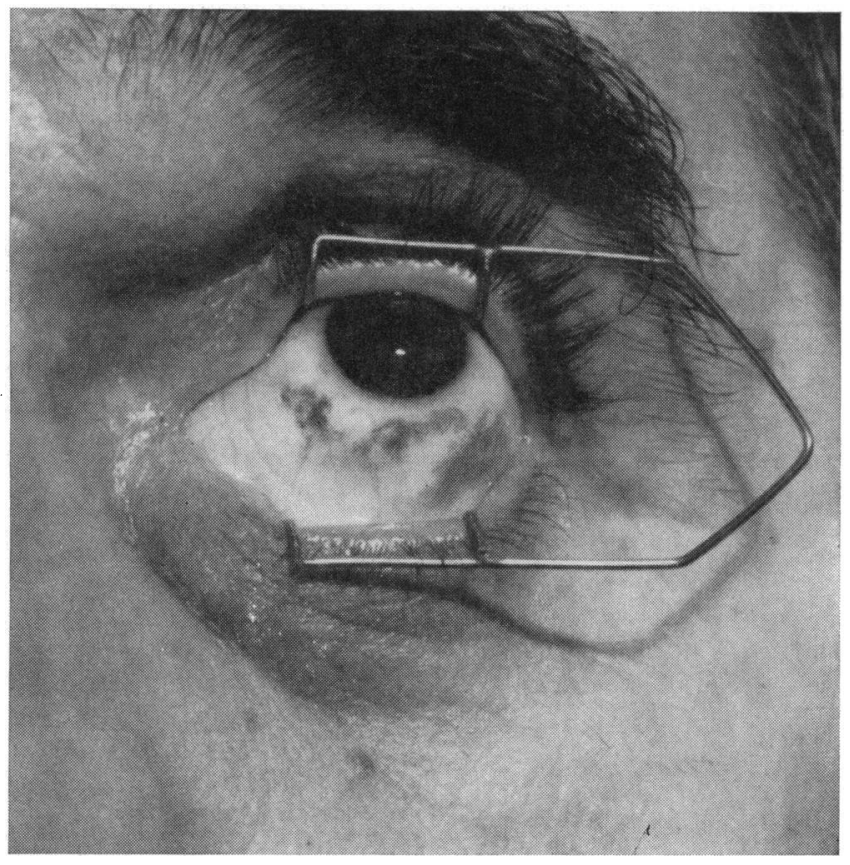

Fig. 1.-Clinical appearance, showing pigmentation of the skin of the eyelids and of the bulbar conjunctiva.

* Received for publication February 26, 1968

$\dagger$ Address for reprints: Institute of Ophthalmology, Università di Siena, Italy. 
Examination.-The visual acuity was 5/5 with a minimal correction in the right eye and 5/7.50 with the same correction in the left. He was found to have a large perimetric defect in the upper and temporal quadrants of the left eye. He had dark blue pigmentation around the left eye and melanosis of the conjunctiva of this eye had been present since birth (Fig. 1).

Ophthalmoscopic examination revealed a large inferior retinal detachment with a definite lack of trans-illumination from 4 to 7 o'clock, and ultrasonic investigation indicated a solid mass in this area. Thörmhalen's test on the urine was negative and general physical examination did not disclose any metastases.

Surgery.-The left eye was enucleated under general anaesthesia.

\section{Pathological Findings}

Macroscopic Examination.-The sclera contained many patches of brown pigment but no extraocular nodules were found. On opening the globe a brownish tumour measuring $6 \times 6 \times 4 \mathrm{~mm}$. was found in the inferior quadrant of the eye under the detached retina (Fig. 2).

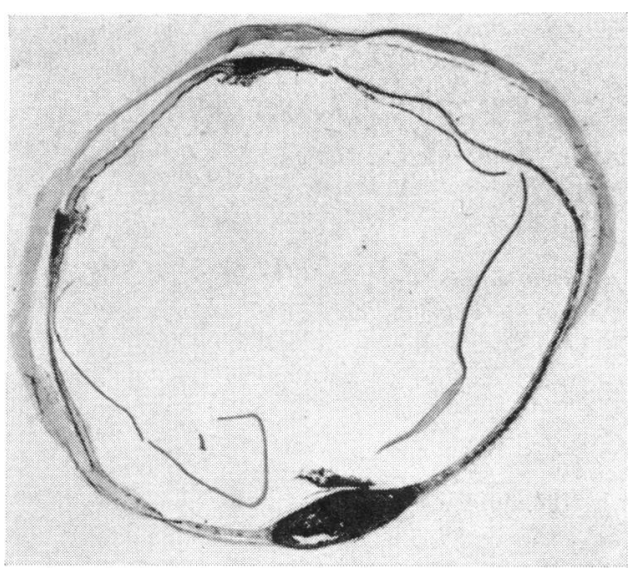

FIG. 2.-Section of eye, showing choroidal tumour.

FIG. 3.-Malignant melanoma of choroid, showing typical mixed cell appearance. $\times 514$.

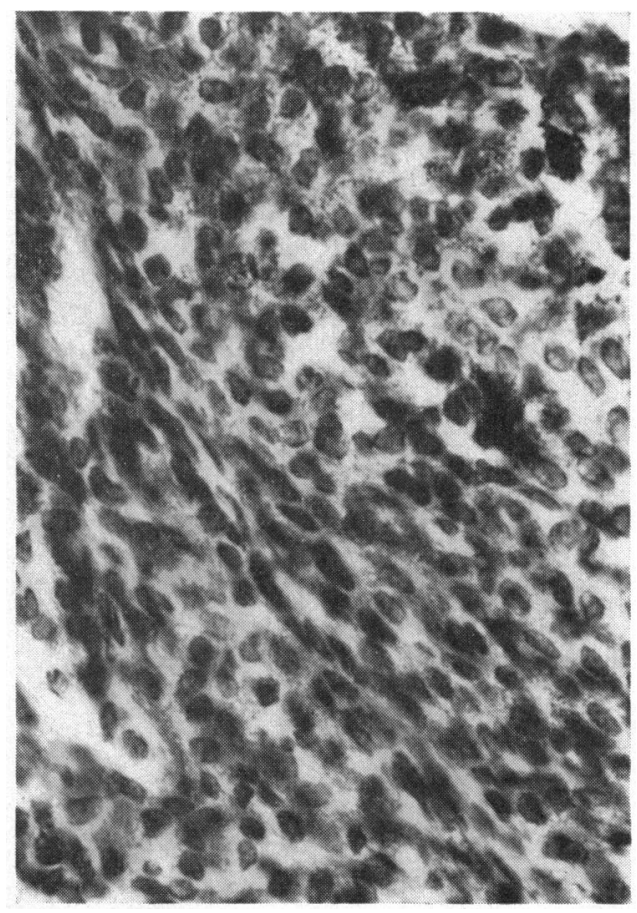

Microscopic Examination.-The heavily-pigmented choroidal tumour consisted of cells with small spindle-shaped nuclei without nucleoli together with several epithelioid cells containing vesicular nuclei and some multinuclear cells (Fig. 3). The tumour contained necrotic and haemorrhagic areas and tumour cells extended into the sclera although no true extrascleral extensions were found.

\section{Discussion}

The association of an oculodermal melanosis with a malignant melanoma of the choroid has been reported on only six occasions, always in Caucasians. It seems reasonable to assume that the absence of this association in Orientals is due to racial and genetic factors; 
malignant melanomata of the choroid rarely occur in non-Caucasians (Paul, Parnell, and Fraker, 1962) and there are no reports of this tumour in the Japanese literature between 1957 and 1966. Furthermore, malignant melanomata of the skin occur more frequently in Caucasians than in coloured people.

From a review of the literature it appears that malignant change in the naevus of Ota in Caucasians occurs in about 15 per cent. of cases, a figure similar to the 25 per cent. of cases of melanosis bulbi that undergo malignant change (Reese, 1964).

\section{Summary}

A case of malignant melanoma of the choroid in association with a naevus of Ota is presented. Naevus of Ota, hitherto regarded as benign, should be regarded as potentially dangerous, particularly in Caucasians.

\section{REFERENCES}

Albert, D. M., and ScheIE, H. G. (1963). Arch. Ophthal. (Chicago), 69, 774.

BENEDICT, W. L. (1949). Amer. J. Ophthal., 32, 763.

DORSEY, C. S., and MONTGOMERY, H. (1954). J. invest. Derm., 22, 225.

Font, R. L., ReYNolds, A. M., Jr., and Zimmerman, L. E. (1967). Arch. Ophthal., 77, 513.

Gomez Gonzales, J., Roselli, A., and Rodriguez, A. (1965). Univ. Med. Colombia, 7, 47.

HAGler, W. S., and Brown, C. C. (1966). Trans. Amer. Acad. Ophthal. Otolaryng., 70, 817.

HulKe, J. W. (1861). Ophthal. Hosp. Rep., 3, 279.

JAY, B. (1965). Brit. J. Ophthal., 49, 359.

MakLeY, T. A., and KING, C. M. (1967). Trans. Amer. Acad. Ophthal. Otolaryng., 71, 638.

Paul, E. V., Parnell, B. L., and Fraker, M. (1962). Int. ophthal. Clin., 2, 387.

RoY, P. E., and SChAEFFer, E. M. (1967). Surv. Ophthal., 12, 130.

ReEse, A. B. (1964). In "Ocular and Adnexal Tumours. New and Controversial Aspects", ed. M. Boniuk, p. 353. Mosby, St. Louis.

Tosti, E., and RenNa, V. (1966). Boll. Oculist., 45, 862.

VolPI, U. (1966). Ann. Ottal., 92, 219.

WiLlis, R. A. (1960). "Pathology of Tumours", 3rd ed., p. 917. Butterworths, London. 